\title{
Irrigation Water Pricing in Tunisia: Issues for Management Transparency
}

\author{
Chokri Thabet ${ }^{1}$ and Ali Chebil*2
}

\author{
${ }^{1}$ Ecole Supérieure d'Horticulture et d'Elevage de Chott Mariem (Tunisie) \\ ${ }^{2}$ Institut National de Recherches en Génie Rural, Eaux et Forêts de Tunis
}

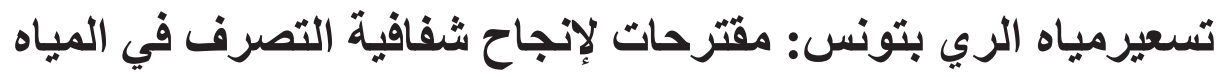

\author{
ش. ثابت و أ. شبيل
}

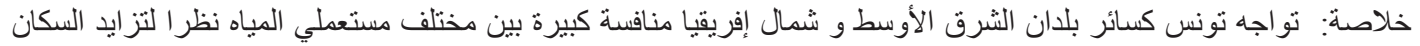

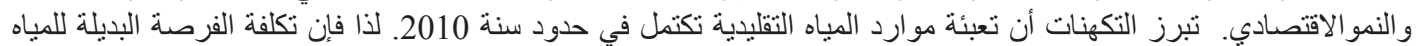

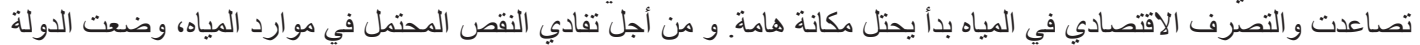

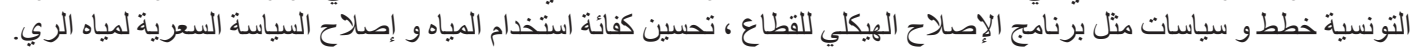

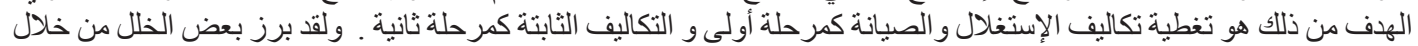

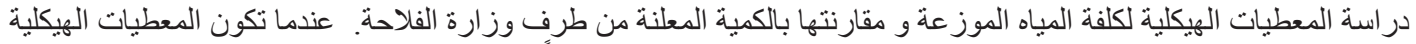

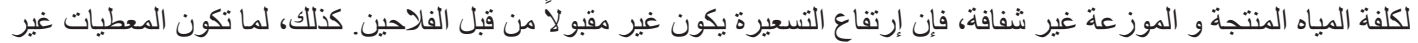

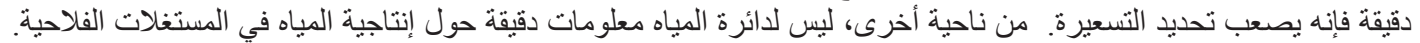

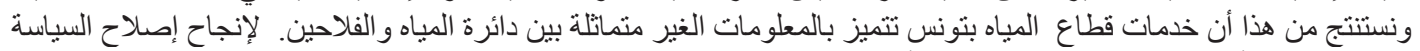

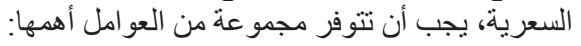

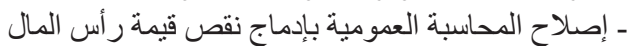

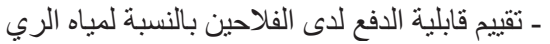
إلى جانب ذلك، فإن إحداث سوق حقوق المياه يمكن أن يساهم في حل مشكلة عدم تناسق المعلومات وضمان النجاعة الاقتصادية.

ABSTRACT: Tunisia is facing increasing competition for water among users due to population and economic growth. Projections show that the water resources will be fully used by 2010. As a result, the opportunity cost of water has risen significantly. In order to cope with potential water shortages, the Tunisian government has undertaken a set of policies and technical measures, such as institutional reforms, improving the efficiency of water delivery network and water pricing policies reforms. It has been observed that cost estimation of water produced and delivered is not transparent. Thus any increase in water price is opposed by farmers. Data is not consistent, making the establishment of a water pricing scheme difficult. Besides, the water authority lacks accurate information on water productivity at farm level leading to asymmetric information on the side of the authorities as well as on the side of the farmers. For a successful reform of the irrigation water pricing policy two conditions have to prevail: i) integration of the accounting system of capital costs with an analytical approach and ii) assessing farmers' willingness to pay for irrigation water. Finally, the implementation of a water rights system could be an alternative to solve the asymmetric information problem and improve the economic efficiency.

Keywords: Water cost, accounting, cost recovery, reforms.

\section{Introduction}

The water resources in Tunisia are scarce and their quality is degrading. Traditionally, the water policy in Tunisia was oriented much more towards supply than demand management. However, the increase of supply reached its limits and several problems emerged, such as overexploitation of the resources, increase of marginal cost, low cost recovery, inter-

\footnotetext{
* Corresponding author.. E-mail: chebil.ali@iresa.agrinet.tn
} 
and intra-sector conflicts, misallocation and lack of efficiency. As the per capita availability of water supplies declines and the marginal costs of securing additional supplies rise, water authorities are compelled to explore new approaches to improve the management of water resources. Since the nineties, international organizations (FAO, 1997; World Bank, 1994) and water experts (Horchani, 1994; Mattoussi, 2002; Chohin-Kuper et al., 2002) suggested a shift in policy towards water demand management taking into account the economic value of water. Economic theory suggests the use of economic instruments to fulfill this target, such as water pricing, quotas and a water market. It is commonly agreed today that water pricing can be an effective tool of water demand management (Johansen et al., 2002).

During the last decades, volumetric pricing has been adopted wherever possible in Tunisia. However, irrigation water prices have been set at very low levels for a long time and thus were disconnected from costs, mainly due to socio-economic considerations (Ministry of Agriculture, 1998; Thabet, 2003). This resulted in an inefficient use of the resource as well as heavy subsidies that significantly contributed to the public budget deficit. These problems are likely to be aggravated by the increased demand of water by the non-agricultural sectors forecast by national planners. To cope with this situation, the Tunisian government developed a water saving program including irrigation water pricing reform. The recommended annual rise in water prices was $9 \%$ in real terms, which is equivalent to $15 \%$ in nominal terms. This rate of increase has been adopted since 1990 (Hamdane, 2002). Public authorities aimed first to recover the variable costs related to the operation and maintenance (O\&M) and later the fixed costs in the long run. As a result of this policy, farmers were dissatisfied because of the relatively high water prices, which were not accompanied by any improvement in water services.

In this paper, we assess the Tunisian water pricing policy and its coherence regarding the used pricing method and the pursued objectives. This will allow understanding of the reasons behind farmer's dissatisfaction and propose measures that can be implemented for sustainable water demand management.

\section{Water Supply in Tunisia}

The total potential of water resources in the country is about 4.7 billion $\mathrm{m}^{3}$, of which 2.7 billion $\mathrm{m}^{3}$ is derived from surface water and 2 billion $\mathrm{m}^{3}$ from groundwater (Table 1). The water resources are unevenly distributed across the country, with $60 \%$ located in the North, $18 \%$ in the Center, and $22 \%$ in the South. Good quality water resources, that have a salinity below $1.5 \mathrm{~g} / \mathrm{L}$ are distributed as follows: $72 \%$ of surface water resources, $8 \%$ of shallow groundwater, and $20 \%$ of deep groundwater. The nonconventional water resources (reclaimed wastewater and desalinated water) represent only $5 \%$ of the total available resources. Desalinization of brackish groundwater using reverse osmosis is under operation in the Kerkenah Islands and in the city of Gabes, supplying 7 million $\mathrm{m}^{3}$ per year of drinking water. The water resources management and planning are outlined in the country's five-year development plans. Investments in the water sector were about $45 \%$ of the

Table 1. Water resources in Tunisia $\left(\mathrm{Mm}^{3}\right)$.

\begin{tabular}{lrrr}
\hline & Potential & Accessible & Available \\
\hline Surface water & 2700 & 1405 & 930 \\
Shallow aquifers & 719 & 720 & 720 \\
Deep aquifers & 1250 & 997 & 997 \\
Conventional resources total & 4669 & 3122 & 2647 \\
Reclaimed wastewater & 250 & 120 & 120 \\
Desalinated water & & 7 & 7 \\
Non-conventional resources total & 250 & 127 & 127 \\
\hline Total water resources & 4919 & 3249 & 2774 \\
\hline
\end{tabular}

Source: Ministry of Agriculture, 1998. 
Table 2. Water consumption by sector $\left(\mathrm{Mm}^{3}\right)$.

\begin{tabular}{lrrrrr}
\hline & Irrigation & Domestic & Industry & Tourism & Total \\
\hline Conventional water & 2090 & 290 & 104 & 19 & 2503 \\
No-conventional water & 25 & 0 & 0 & 0 & 25 \\
\hline Total & 2115 & 290 & 104 & 19 & 2528 \\
$\%$ & 84 & 11 & 4 & 1 & 100 \\
\hline
\end{tabular}

Source: Ministry of Agriculture, 1998.

total Ministry of Agriculture's budget during the $10^{\text {th }}$ economic, social and development plan (Bahri, 2001).

\section{Water Demand and Irrigated Agriculture}

The total amount of consumed water is estimated to be 2.5 billon $\mathrm{m}^{3}$, which is distributed between users as follows: agriculture $84 \%$, domestic use $11 \%$, industrial sector $4 \%$ and tourism $1 \%$ (Table 2). The irrigated area is presently estimated at 412,000 ha. Three types of irrigation management exist (Table 3):

- Private management applies to $40 \%$ of the total irrigated area and relates to areas irrigated with groundwater. Farmers in these areas are responsible for the investment and operation costs of their individual water systems.

- Associative management, undertaken by water users associations (Goupement d'Intérêt Collectifs GIC), cover $36 \%$ of the total irrigated area. The collective hydraulic networks are set up through public funds, but their management is delegated to GIC.
- Management of large irrigated schemes, which make up to $24 \%$ of the total irrigated area, is still entrusted to public agencies with financial autonomy, but under the supervision of the Ministry of Agriculture. Farmers participate in the investment under the Agricultural Reform Law and pay the total or part of the water O\&M cost.

The irrigated sector represents $7 \%$ of the agricultural area and accounts for $35 \%$ of the total agricultural value, $20 \%$ of agricultural exports and $27 \%$ of the agricultural labor force. The irrigated area produces $95 \%$ of the vegetables, $70 \%$ of fruits and $30 \%$ of the dairy output. The irrigated sector will inevitably face more acute competition in the near future due to the water demand increase in the service and industrial sectors, which are considered economically more competitive.

\section{Water Pricing in Tunisia and Cost Recovery}

Tunisian water pricing experiences

Since the promulgation of the land reform laws in 1962, measures have been prepared to make farmers

Table 3. Irrigated areas and water sources in Tunisia.

\begin{tabular}{|c|c|c|c|c|}
\hline & \multirow{2}{*}{$\begin{array}{c}\begin{array}{c}\text { Private irrigated } \\
\text { perimeters (ha) }\end{array} \\
\text { Managed by } \\
\text { individual farmers }\end{array}$} & \multicolumn{2}{|c|}{$\begin{array}{l}\text { Public irrigated } \\
\text { perimeters (ha) }\end{array}$} & \multirow{2}{*}{ Total (ha) } \\
\hline & & $\begin{array}{l}\text { Managed } \\
\text { by CRDA }\end{array}$ & $\begin{array}{l}\text { Managed } \\
\text { by GIC }\end{array}$ & \\
\hline Surface water & & 84,000 & 59,000 & 143,000 \\
\hline Tubewells & 10,000 & 8,000 & 74,000 & 92,000 \\
\hline Shallow wells & 145,000 & & & 145,000 \\
\hline Springs and intermittent streams & 10,000 & & 15,000 & 25,000 \\
\hline Reclaimed wastewater & & 5,000 & 2,000 & 7,000 \\
\hline Total & 165,000 & 97,000 & 150,000 & 412,000 \\
\hline
\end{tabular}

Source: DGGREE (2004). 
contribute to the water investments. At the beginning of the 1970 's, a water pricing method was been adopted in public areas that benefited from public investments. The method was based on an arbitrary fixed tax per hectare in order to constrain users to develop irrigation and to guarantee a minimum cost recovery (Ministry of the Economy, 1971). During the same period, the water management authority stressed that water price should be judiciously calculated to give the users consciousness of the need to improve water efficiency (Ben Khelil, 1971). The four-year economic and social development plan (1973-76) was explicit on the irrigation objectives:

- Producing water at a minimum cost,

- Improving water productivity,

- Intensifying the mobilization of renewable water, and

- Basing water infrastructure development on economic criteria.

In 1975 the Water Code was promulgated (law $\mathrm{n}^{\circ} 75-16$ ), which consolidated the institutional measures and linked the allocation of water to its highest value (Ministry of Agriculture, 1978). During the seventies, the Development Office of the Valley of Medjerda (OMVVM)) undertook several studies aimed at concretizing the pricing methods. These studies were intended to take into account the following three requirements:

- Those who benefit from water should pay its cost,

- Pricing shouldn't compromise the irrigation development by high tariffs, and.

- Pricing must be conceived as an integral part of a global development strategy.

Other attempts at water pricing have been made, particularly in the irrigated areas of the Medjerda river high valley. They differ partly from those of the Medjerda lower valley by taking into account the soil quality, crop rotation and the socio-economic environment. The OMVVM conceived a two-tier pricing method, which aims to promote water saving without hindering irrigation. The OMVVM (1976) affirmed that the two-tier pricing method was «the most logical and equitable». It includes two terms

- The first block is a fixed levy intended to finance the fixed costs that the user has to pay annually, independently of the volume of water used, and
- The second term is proportional to the water volume.

However, the above method caused problems as irrigation was new to farmers and was not mastered. It was then argued that the increase in the water price could hinder the financial capacity of small farmers. It was suggested that the State should pay the investment cost, at least during a transition period. The increase in water price was postponed until economic conditions improved. However, users were to be warned that at some time they would have to pay the full price of water (OMVVM, 1976).

The indirect advantage of the above-mentioned studies were that they contributed significantly to heighten decision makers' awareness of the need to make users participate in financing irrigation. Following this experience, several attempts at pricing have been made in other irrigated public areas. At the beginning of the eighties, the Ministry of Agriculture launched several studies aiming to base water pricing on farmers ability to pay relative to recovery cost. A study conducted by the National Center of Agricultural Studies (DEGTH, 1980) led to a pricing system as described previously (the two-tier pricing) with some modifications:

- A fixed annual fee,

- Consideration of the agricultural development objectives regarding the strategic crops (cereal, sugar beet etc.) charged lower tariffs for water use, and

- The establishment of high water prices during the high consumption periods.

The application of the above pricing mechanisms was lax and resulted in low rates of cost recovery, ranging between 19 and $36 \%$ of the total water cost. According to the World Bank (1980), the investment costs were not covered at all and the O\&M costs were partially reimbursed. The report insisted on recommending to the Tunisian government the need to recover the «greatest part possible of the investment costs».

The Agricultural Structural Adjustment Program started in 1986 and constituted a new shift in the Tunisian economic policy. Indeed, the AAP recommended coherent pricing and subsidizing policies during the implementation of the $8^{\text {th }}$ and the $9^{\text {th }}$ 
Table 4. Annual increase of the average irrigation water price.

\begin{tabular}{lrrr}
\hline Year & $\begin{array}{r}\text { Water } \\
\text { average } \\
\text { price }\end{array}$ & $\begin{array}{r}\text { Rate of } \\
\text { water price } \\
\text { increase } \\
\left(\mathbf{T D} / \mathbf{m}^{\mathbf{3}}\right)\end{array}$ & $\begin{array}{r}\text { Invoiced } \\
\text { volume } \\
\left(\mathbf{M m}^{\mathbf{3}}\right)\end{array}$ \\
\hline 1995 & 0.060 & - & 175 \\
1996 & 0.069 & 15.0 & 162 \\
1997 & 0.084 & 21.7 & 186 \\
1998 & 0.092 & 9.5 & 169 \\
1999 & 0.098 & 6.5 & 174 \\
2000 & 0.105 & 7.1 & 219 \\
2001 & 0.105 & 0.0 & 197 \\
2002 & 0.110 & 4.8 & 239 \\
2003 & 0.110 & 0.0 & 159 \\
\hline Mean & 0.093 & 8.1 & 187 \\
\hline
\end{tabular}

Source: DGGREE (1995-2003).

$1 \mathrm{TD} \approx 0.76 \mathrm{US} \$$

economic plans. The objective of making farmers pay for equipment renewal, in addition to the O\&M costs, was clearly stated (Ministry of Agriculture, 1997).

\section{Current water pricing}

Nowadays, several procedures are used to measure and invoice irrigation water. When the volume of water can be measured, using meters or by the water flow and the recorded time, water is priced by volume. A fixed sum per irrigated area is used when metering is not possible.

Irrigation water prices are spatially and temporally variable. In 2000, they ranged between 0.116 Tunisian
Dinars per cubic meter $\left(\mathrm{TD} / \mathrm{m}^{3}\right)$ in the Central coast and $0.035 \mathrm{TD} / \mathrm{m}^{3}$ in the South (Hamdane, 2002). Regarding temporal variability, the applied prices have recorded a continuous rise to take into account, at a first step, the inflation rate. In the second step, the objective was to ensure cost recovery of the delivery network and O\&M costs. The long term purpose of water pricing is to achieve the total cost recovery of water services, including fixed costs. This assumes that these costs are well identified and known.

In the frame of the AAP, the recommended annual rise in water price is $9 \%$ in real terms, which is equivalent to $15 \%$ in nominal terms, given an inflation rate of $6 \%$. The average water price of a cubic meter, in the irrigated public areas managed by the CRDA, has increased from $0.060 \mathrm{TD} / \mathrm{m}^{3}$ in 1995 to $0.110 \mathrm{TD} /$ $\mathrm{m}^{3}$ in 2003 , with some annual variability as reported in Table 4. The average nominal annual increase of water tariffs amounted to 8.1\% during 1995-2003, which is higher than the mean inflation rate during the same period (3.9\%). However, the times of drought, particularly during the period 2001-2003, and concern about farmer's capacity for payment, have made it difficult to maintain the targeted rate of water price increase.

\section{Irrigation water costs}

In the absence of reliable cost accounting within the regional water agencies (CRDA), the total costs of the irrigation water, including fixed costs, are not well identified. The available information from the Agricultural Ministry is related to O\&M cost.

Table 5. Structure of water operating and maintenance costs at national level (1000 TD).

\begin{tabular}{lrrrrr}
\hline Year & Personal & Energy & $\begin{array}{r}\text { Consumable } \\
\text { Products }\end{array}$ & Others & Total \\
\hline 1995 & 5,663 & 3,198 & 1,592 & 3,399 & 13,853 \\
1996 & 5,570 & 2,306 & 2,042 & 2,755 & 12,675 \\
1997 & 5,653 & 2,588 & 1,586 & 4,469 & 14,297 \\
1998 & 5,758 & 2,581 & 1,820 & 4,827 & 14,988 \\
1999 & 5,828 & 2,339 & 956 & 5,666 & 14,791 \\
2000 & 5,934 & 2,983 & 2,411 & 5,361 & 16,690 \\
2001 & 6,030 & 2,821 & 1,658 & 6,153 & 16,663 \\
2002 & 5,412 & 3,131 & 1,320 & 8,544 & 18,409 \\
2003 & 5,725 & 2,472 & 729 & 6,245 & 15,172 \\
\hline Average & 5,730 & 2,713 & 1,568 & 5,269 & 15,282 \\
Percentage (\%) & 37.5 & 17.6 & 10.4 & 34.5 & 100 \\
\hline
\end{tabular}

Source: DGGREE (1995-2003). 
Table 6. Trend of annual average operation and maintenance costs of public perimeters managed by CRDA.

\begin{tabular}{|c|c|c|c|}
\hline Year & $\begin{array}{r}\text { Total Water } \\
\text { O\&M Costs } \\
(1000 \text { TD) }\end{array}$ & $\begin{array}{r}\text { Invoiced } \\
\text { Volume } \\
\left(\mathrm{Mm}^{3}\right)\end{array}$ & $\begin{array}{r}\text { Water } \\
\text { O\&M } \\
\text { Costs } \\
\left(\mathrm{TD} / \mathbf{~ m}^{3}\right)\end{array}$ \\
\hline 1995 & 13,853 & 175,017 & 0.079 \\
\hline 1996 & 12,675 & 161,578 & 0.078 \\
\hline 1997 & 14,297 & 186,371 & 0.077 \\
\hline 1998 & 14,988 & 169,079 & 0.089 \\
\hline 1999 & 14,791 & 174,417 & 0.085 \\
\hline 2000 & 16,690 & 218,793 & 0.076 \\
\hline 2001 & 16,663 & 196,706 & 0.085 \\
\hline 2002 & 18,409 & 238,605 & 0.077 \\
\hline 2003 & 15,172 & 158,757 & 0.096 \\
\hline Total & 137,541 & $1,679,246$ & 0.082 \\
\hline
\end{tabular}

Source: DGGREE (1995-2003).

A study undertaken by the General Director of Rural Engineering (Hamdane, 2002), based on data received from the various CRDA, showed an average cost structure of irrigation water as follows:

- Personal costs: $37.50 \%$

- Energy costs: $17.60 \%$

- Consumables: $10.40 \%$

- Others: $34.50 \%$

Table 7. Trend of water subsidy regarding the O\&M costs $\left(\mathrm{TD} / \mathrm{m}^{3}\right)$.

\begin{tabular}{lcrr}
\hline Year & $\begin{array}{r}\text { Water } \\
\text { O\&M } \\
\text { Costs }\end{array}$ & $\begin{array}{r}\text { Selling } \\
\text { Price }\end{array}$ & $\begin{array}{r}\text { Unitary } \\
\text { Subsidy* }\end{array}$ \\
\hline 1995 & 0.079 & 0.060 & 0.019 \\
1996 & 0.078 & 0.069 & 0.009 \\
1997 & 0.077 & 0.084 & -0.007 \\
1998 & 0.089 & 0.092 & -0.003 \\
1999 & 0.085 & 0.098 & -0.003 \\
2000 & 0.076 & 0.105 & -0.029 \\
2001 & 0.085 & 0.105 & -0.020 \\
2002 & 0.077 & 0.110 & -0.033 \\
2003 & 0.096 & 0.110 & -0.014 \\
\hline Average & 0.082 & 0.093 & -0.011 \\
\hline
\end{tabular}

Source : DGGREE (1995-2003).

"The negative value of the subsidy means that the selling price is higher than the water O\&M cost and covers part of the renewal costs.
The water O\&M cost structure at national level for the period 1995-2003 is reported in Table 5. The shown O\&M costs must be taken as indicative because they are not computed accurately. Indeed, the report stresses the difficulties to allocate certain costs. The person can, for example, be employed in several irrigated public perimeters at the same time. It is the same for materials and equipment, transport equipment and heavy tools, which are used in several irrigated public areas, but no registration of the timing exist to allow the distribution of the cost among the irrigated areas. By taking into account the invoiced total water volume, the resulting average O\&M cost is reported in Table 6 .

For the period 1995-2003, the water average O\&M cost was around $0.082 \mathrm{TD} / \mathrm{m}^{3}$. However, it needs to be borne in mind that these costs don't include the costs for heavy reparations.

\section{Cost recovery problem}

Table 7 shows that at national level, recovery of the O\&M costs of irrigation water have been achieved since 1997 and part of the equipment renewal costs began to be recovered. However, it is necessary to relativize these figures because of the inaccuracies in the calculation of this cost. For example, for certain years, the income includes the late payment for unpaid former years. The variation of rate recovery is also due to the fact that during drought years, irrigation water demand increases, leading to higher recovery level and vice-versa.

The examination of the rate of recovery of O\&M costs reveals an inconsistency that must be emphasized. If we compare the amount of water consumed by the agricultural sector (2115 million $\left.\mathrm{m}^{3}\right)$ with the invoiced volume of the irrigated areas managed by the CRDA in 2003 (159 millions $\mathrm{m}^{3}$ ), it is clear that the latter represents only $8 \%$ of the total agricultural water consumption. By adding the estimated volume of water consumed by the GIC (241 million $\mathrm{m}^{3}$ ) and the private irrigated perimeters $\left(700\right.$ million $\left.\mathrm{m}^{3}\right)$, the consumption of the agricultural sector totals to 1100 million $\mathrm{m}^{3}$. Hence the gap between the distributed volume for irrigation and the invoiced volume is about 1000 million $\mathrm{m}^{3}$. In this context, one should ask: what is the cost of this volume of water? The O\&M costs and the unitary subsidy per cubic meter of water are calculated on the basis of the invoiced volume for all the CRDA and not the total distributed 
amount of water (see Hamdane, 2002). Furthermore, prices are fixed for all the irrigated areas managed by the CRDA according to these costs. Regarding the irrigated perimeters managed by the GIC, water prices are supposed to be fixed by the GIC members but a recent study (Treyer, 2002) has criticized the heavy supervision and direct intervention of the CRDA in the management of these areas and particularly in fixing water prices. If such is the case, the irrigation water subsidy estimation is thus underestimated because it depends on the invoiced water volume only. Consequently, when the cost structure of water produced and delivered is not transparent, any increase in water price to farmers is not justified and can lead to dissatisfaction. Furthermore, when data is not consistent, the establishment of a water pricing scheme will be difficult since the rate of subsidy is not clearly determined.

Finally, the water authority lacks accurate information on the productivity of water at farm level. Conscious of the economic and social role that the irrigated sector plays in Tunisia, farmers' capacity to pay becomes a determinant factor in the establishment of the irrigation water price level (Hamdane, 2002). Hence, the water service in Tunisia is characterized by asymmetric information on the side of the authorities as well as on the side of the farmers.

For a long time, the accepted idea is that a regulated public agency can ensure the best water allocation if certain conditions related to production technology are met. However, this supposes that the authorities have suitable tools to determine the prices and to organize transfers between economic sectors. Furthermore, cost estimation requires a good knowledge of the production costs structure.

For a successful reform of the irrigation water pricing policy, some conditions need to be met:

- reforming the public accounting system, which should integrate capital depreciation and an analytical approach behind invoicing;

- assessing farmers willingness to pay for irrigation water; and

- identifying the priority goals for the irrigation water pricing policy.
All these elements should facilitate the implementation of a more transparent public environment, from which the reformer will be able to persuade farmers more easily. A promising alternative to be explored could be the implementation of water rights and water markets, since it solves the asymmetric information problem and improves economic efficiency. Indeed, several studies have shown that markets can serve as institutional arrangements for optimal allocation of the water resources (Mattoussi, 2002; Bachta et al., 2004; Diao and Roe, 2003; Zekri and Easter, 2005) when transferable water rights are well-defined. This implies deep-rooted legal and institutional reforms to guarantee the efficiency of such markets. The results could be confirmed with a pilot study in a chosen region of the country. Moreover, the transfer of O\&M responsibilities to water users' organizations could improve the estimation of water cost and facilitate the implementation of water markets. What is urgently needed is the devolution of the irrigation schemes to farmers to operate them themselves, instead of their current apparent and ineffective participation.

\section{Conclusion}

Irrigation water prices in Tunisia have been set at low levels for a long time and were disconnected from costs, mainly due to socio-economic considerations. This situation led water users to consider water as «heaven sent» and not as a scarce resource. This resulted in high increases in water demand as well as huge subsidies that significantly contributed to the public budget deficit. To cope with this situation, a new water pricing method was adopted in the 1990's. It consisted of increasing water prices at an annual rate of $9 \%$ in real terms. This policy aimed to recover O\&M costs in the first step and some capital costs in a second step. The main difficulty encountered when implementing the new water pricing policy was acceptance by farmers of the continuous increase in water prices.

Examination of the cost structure of delivered irrigation water and consumed water in the agricultural sector revealed some inconsistencies. First, the water cost is calculated as a ratio of O\&M costs to the invoiced volume in spite of the delivered volume. Second, the fixed costs are not considered in the 
estimation. When the cost structure of water produced is not transparent any increase in water price is hardly justifiable. We argue that knowledge of the full-cost is the most important step in water policy formulation. This is crucial because the rate of subsidy of irrigation water depends on the total volume of water delivered, and the establishment of a water pricing scheme that targets the removal of these subsidies can not be implemented successfully.

For successful reform of the irrigation water pricing policy, two conditions must prevail: reform of the public accounting system to integrate capital depreciation and an analytical approach behind invoicing; and assessing farmers' ability to pay. These elements should facilitate the implementation of a more transparent public environment, providing farmers with the right information to convince them to participate. The implementation of a water rights system could be an alternative, since it solves the asymmetric information problem and improves the economic efficiency.

\section{Acknowledgement}

This work was funded in the frame of the research project "Gestion de la demande d'eau agricole et politiques de tarification en Tunisie et en Espagne". We are grateful to the Spanish Agency for International Cooperation (AECI) and the Tunisian Ministry of Research which have contributed funding to this research.

\section{References}

Bachta, M.S., A. Ben Mimoun, L. Zaibet and L. Albouchi. 2004. Simulation of water market in Tunisia: A case stuty of GIC Melalsa - Kairouan., Modernisation de l'agriculture irriguée, 19-23 Avril, Rabat, Morocco. pp 24-33.

Bahri, A. 2001. Water resources development and management in Tunisia. 15 p. www.gwpmed.org/ products_documents/country_reports/Tunis.pdf.

Ben Khelil, A. 1971. Etablissement d'une tarification $d u m^{3} d$ 'eau d'irrigation. Ministère de l'Agriculture. $23 \mathrm{pp}$.

Chohin-Kuper, A., T. Rieu and M. Montginoul. 2002. Les outils économiques pour la gestion de la demande en eau en Méditerranée. Série Irrigation, June 2002, pp 6-12. Cemagref.

DEGTH. 1980. Recouvrement des investissements hydrauliques en Tunisie. Volume 1. Rapport de synthèse. Ministry of Agriculture, Tunisia, $150 \mathrm{pp}$.
Diao X. and T. Roe. 2003. Can a water market avert the «double-whammy» of trade reform and lead to a «win-win» outcome? Journal of Environmental Economics and Management 45:708-723.

Direction Générale du Génie Rurale et d'exploitation des Eaux (DGGREE). 2004. Rapport de synthèse de la situation des GIC d'irrigation. Ministère de l'Agriculture. $89 \mathrm{pp}$.

DGGREE. 1995-2003. Evaluation du coût d'exploitation et de maintenance dans les PPI en gestion directe par le CRDA.

FAO. 1997. Proceedings of the Expert Consultation On National Water Policy Reform in the Near East. Cairo, Egypt, 222 pp.

Hamdane, A. 2002. La tarification des eaux agricoles en Tunisie. Forum on Water Demand Management, Beyrouth, Libanon, 13 pp.

Horchani, A. 1994. Gestion des ressources en eau en Tunisie. Working paper. Ministry of Agriculture, Tunisia, $10 \mathrm{pp}$.

Johansen, R.C., Y. Tsur, T.L. Roe, R. Doukali and A. Dinar. 2002. Pricing irrigation water: a review of theory and practice. Water Policy $4: 173-199$.

Mattoussi, M.S. 2002. Gestion durable de la demande en eau : la seule alternative capable de relever les défis menaçant. Eighth Annual Conference, Economic Research Forum, 17-18 January 2002, Cairo. www.erf.org.eg/html/Labor_8th

Ministry of Agriculture.1978. Code des eaux. Imprimerie officielle. Tunisia. $38 \mathrm{pp}$.

Ministry of Agriculture. 1997. Etude de la gestion et de la Tarification de l'eau d'irrigation au niveau des périmètres irrigués : Diagnostic de la gestion actuelle. CNEA and BRL Ingineering. $180 \mathrm{pp}$.

Ministry of Agriculture. 1998. EAU 21 : Stratégie du secteur de l'eau en Tunisie à long terme, 2030. Rapport final. $400 \mathrm{pp}$.

Ministry of the Economy, Tunisia. 1971. L'eau facteur décisif d'aménagement, Groupe Huit. 156 pp.

OMVVM. 1976. Etude de la tarification de l'eau d'irrigation dans la base vallée de la Medjerda. Office de Mise en Valeur de la Vallée de la Medjerda. Ministère de l'Agriculture, Tunisie. pp 48.

Thabet, C. 2003. Réforme de la politique des prix de l'eau d'irrigation en Tunisie : approche en équilibre général. Ph.D dissertation, ENSA de Rennes, France.

Treyer, S. 2002. Analyse des stratégies et prospectives de l'eau en Tunisie. Plan Bleu, Sophia Antipolis. $152 \mathrm{pp}$.

World Bank. 1994. La gestion de l'eau en Tunisie. La gestion de l'eau dans les pays Maghrébins. World Bank. $150 \mathrm{pp}$.

Zekri, S. and W. Easter. 2005. Estimating the potential gains from water markets: a case study from Tunisia. Agricultural Water Management 72:61175. 